\title{
Digital learning object for diagnostic reasoning in nursing applied to the integumentary system
}

\author{
Objeto virtual de aprendizagem sobre o raciocínio diagnóstico \\ em enfermagem aplicado ao sistema tegumentar \\ Objeto virtual de aprendizaje en el razonamiento diagnóstico \\ en enfermería aplicado al sistema tegumentário
}

\author{
Cecília Passos Vaz da Costa ${ }^{a}$ \\ Maria Helena Barros Araújo Luz ${ }^{b}$
}

D0l: $\quad$ http://dx.doi.org/10.1590/19831447.2015.04.54128

\footnotetext{
a Fundação Municipal de Saúde. Diretoria Regional de Saúde Centro Norte. Teresina, Piauí, Brasil.

b Universidade Federal do Piauí. Departamento de Enfermagem. Teresina, Piaúi, Brasil.
}

\begin{abstract}
Objective: To describe the creation of a digital learning object for diagnostic reasoning in nursing applied to the integumentary system at a public university of Piaui.

Method: A methodological study applied to technological production based on the pedagogical framework of problem-based learning. The methodology for creating the learning object observed the stages of analysis, design, development, implementation and evaluation recommended for contextualized instructional design. The revised taxonomy of Bloom was used to list the educational goals. Results: The four modules of the developed learning object were inserted into the educational platform Moodle. The theoretical assumptions allowed the design of an important online resource that promotes effective learning in the scope of nursing education. Conclusion: This study should add value to nursing teaching practices through the use of digital learning objects for teaching diagnostic reasoning applied to skin and skin appendages.
\end{abstract}

Keywords: Education, nursing. Educational technology. Nursing diagnosis. Skin.

\section{RESUMO}

Objetivo: Descrever o desenvolvimento de um objeto virtual de aprendizagem sobre o raciocínio diagnóstico em enfermagem aplicado ao sistema tegumentar em uma universidade pública do Piauí.

Método: Pesquisa metodológica aplicada de produção tecnológica que utilizou o referencial pedagógico da educação problematizadora; a metodologia para desenvolvimento do objeto de aprendizagem seguiu as etapas de análise, design, desenvolvimento, implementação e avaliação preconizadas pelo design instrucional contextualizado, e a taxonomia revisada de Bloom foi utilizada para elencar os objetivos educacionais.

Resultados: Os quatro módulos do objeto de aprendizagem desenvolvido foram inseridos na plataforma educacional do Moodle. Os pressupostos teóricos permitiram conceber um material educativo virtual o qual se configura como instrumento importante para a promoção de uma aprendizagem efetiva no âmbito educacional da enfermagem.

Conclusão: Espera-se agregar valor às práticas de ensino da enfermagem mediante utilização de objetos virtuais de aprendizagem no ensino do raciocínio diagnóstico aplicado à pele e aos anexos cutâneos.

Palavras-chave: Educação em enfermagem. Tecnologia educacional. Diagnóstico de enfermagem. Pele.

\section{RESUMEN}

Objetivo: Describir el desarrollo de un objeto virtual de aprendizaje acerca de la enfermería con razonamiento diagnóstico aplicado al sistema tegumentario en una universidad pública en Piauí.

Método: Investigación metodológica aplicada en la producción tecnológica que utiliza el marco pedagógico de la enseñanza basada en problemas, la metodología para el desarrollo del aprendizaje objeto siguió las etapas de análisis, diseño, desarrollo, implementación y evaluación recomendado por el diseño instruccional y contextualizada utilizado la taxonomía revisada de Bloom para enumerar las metas educativas.

Resultados: Los cuatro módulos desarrollados objeto de aprendizaje se insertaron en la plataforma educativa Moodle. Los supuestos teóricos permitieron diseñar un material educativo virtual que se configura como una herramienta importante para promover un aprendizaje eficaz en la educación de contexto de la enfermería.

Conclusión: Se espera agregar valor a las prácticas de enseñanza de enfermería mediante el uso de objetos virtuales de aprendizaje en la enseñanza del razonamiento diagnóstico aplicado a la piel y de la piel apéndices.

Palabras clave: Educación en enfermería. Tecnología educacional. Diagnóstico de enfermería. Piel. 


\section{DINTRODUCTION}

Information and communication technologies (ICT) are present in contemporary society and are reflected in the field of education. Such technologies have aided in the learning process by providing tools that lead to the effective participation of students.

ICTs have boosted the use of computers and the Internet in society with direct consequences on the process of teaching and learning for classroom and distance learning ${ }^{(1)}$.

These technologies have led to the emergence of digital learning objects (DLO), which are educational resources used to form an effective, participatory and flexible virtual learning environment. These objects have a positive impact on nursing education by boosting the acquisition of knowledge and an autonomous and independent learning experience ${ }^{(2)}$.

The DLO can be applied to support the learning process by acting as a construct of information and knowledge that uses a new type of computer-based education ${ }^{(3)}$

Furthermore, the DLO deserves attention within the context of e-learning because it provides an engaging and successful learning experience in an active educational environment that considers knowledge, cognitive skills and the interest of students ${ }^{(4)}$.

The use of ICTs in nursing education provides a new way of learning based on online educational strategies that offer a unique interactive and autonomous perspective to the experience ${ }^{(5)}$.

In clinical practice, diagnostic reasoning in nursing is a cognitive activity that involves the recognition of signs and symptoms of patients, data analysis and judgment of the clinical situations that will result in a diagnosis statement ${ }^{(6)}$. Therefore, the process of diagnosis in nursing requires the knowledge of fields such as anatomy, physiology, pathology, psychology, epidemiology and nursing theories, as well as critical thinking and decision-making skills(7).

Among the various models of diagnostic reasoning in literature, we emphasize effective nursing diagnoses based on the collection and categorization of data, the identification of knowledge gaps, comparisons with standards of normality, the proposition of an etiological relationship and diagnostic inference in order to declare the title of nursing diagnosis that best defines the response of individuals to their health status ${ }^{(7)}$.

In the scope of nursing education and virtual contemporary environments, it is believed that the use of DLOs and other ICT tools based on problem-based learning are considered potential instruments for teaching, learning and improving clinical reasoning. These objects and tools are especially useful for diagnostic reasoning in nursing during assessments of the integumentary system with the consequent formulation of accurate nursing diagnoses that reflect the responses of individuals in relation to real or potential skin problems.

The DLO "Diagnostic Reasoning in Nursing Applied to the Integumentary System" was pedagogically designed from a praxis of investigating the context and needs of the students with awareness and the critical insertion of students into the studied reality and the questioning of that reality. The aim was to narrow the gap between the subject and the experiences by offering nursing students a complementary method to build their own knowledge based on the teaching and learning of diagnostic reasoning from the data collected during the evaluation of skin and cutaneous annexes, and the analysis of clinical situations presented in the case studies.

Based on these considerations, the object of this study was the creation of a digital learning object for diagnostic reasoning in nursing applied to the integumentary system. Consequently, the aim of this paper was to describe the creation of the virtual learning object for nursing diagnostic reasoning applied to the integumentary system at a public university of Piauí, Brazil.

\section{METHOD}

A methodological study applied to technological production. The digital object was created according to the parameters of the ADDIE model (Analysis, Design, Development, Implementation and Evaluation) for contextual instructional design (CID). CID is defined as a process of planning, development and systematic use of methods and techniques for educational projects supported by technology that facilitates the contextualization and functional disposition of the studied subject. It also provides the flexibility and dynamism to plan and produce teaching materials by structuring, modifying and adapting the form of the material to its function ${ }^{(8)}$.

The analysis stage was based on the educational need to promote diagnostic reasoning to assess the integumentary system and provide relevant solutions. This understanding was used to define the objective of the course, the content that would be presented, the pedagogical framework and the preferred media. Bloom's revised taxonomy of educational objectives ${ }^{(9)}$ was used to define the ed- 
ucational objectives of each module. This taxonomy consists of a classification of statements on what is expected that students learn from instruction ${ }^{(9)}$. The 10 goals of the DLO were listed and arranged in the knowledge dimension and the cognitive process dimension recommended by the taxonomy.

The pedagogical framework that was adopted to create the DLO "Diagnostic Reasoning in Nursing Applied to the Integumentary System" was problem-based learning ${ }^{(10)}$. We believe that the questioning and liberating education proposed by this author promotes awareness and changes the behaviour of individuals. In the problem-based practice, the students develop their power of understanding of the world around them by acknowledging the interaction among the parts that make up the entirety of a phenomenon. The problem-based pedagogy triggers a process of internalization, reflection and awareness in which individuals are the active subjects of the construction of knowledge ${ }^{(10)}$.

The design stage was executed from January to April 2014. This stage consisted of preparing the storyboards that serve as scripts or roadmaps of the content that will be produced. The storyboards were created using PowerPoint and converted to Adobe Flash CS5. The DLO was created with PowerPoint, Adobe Flash CS5 and the educational software Hot Potatoes version 6.0 for Windows, which was used together with JQuiz and JClose to prepare the activities for reviewing the content of each module.

The development stage comprised the production and adaptation of educational resources and their inclusion in the virtual learning environment (VLE) of Moodle. This stage included the first usage and compatibility tests of the DLO with Moodle. We chose to offer the DLO in the Moodle VLE because it is an open-source, user-friendly platform that does not require a license.

The DLO was implemented in September and October 2014. During this stage, the DLO was used by 21 students of the seventh, eighth and ninth period of the nursing course of a public higher education institution (HEI) of Piauí. These students accepted to participate in the research and signed an informed consent statement. The DLO was used with the aid of interactive communication resources, such as email, news forums and initial discussion forums on the use of diagnostic reasoning for skin assessments.

The final evaluation stage consisted of a revision of all the content to identify and correct errors. During this stage, the efficacy and effectiveness of the proposed action was also verified to determine whether the produced material truly represented the essence of the content, and whether the organization and breakdown of the content were correct or required additional adjustments.

The study was approved by the Comitê de Ética em Pesquisa of the Federal University of Piauí with protocol CAAE 20228113.8.0000.5214 and opinion 745.398.

\section{QRESULTS}

The DLO "Diagnostic Reasoning in Nursing Applied to the Integumentary System" inserted in Moodle VLE provided by the Centro de Educação à Distância (CEAD) of the Federal University of Piauí is accessed via a username and password at http://www.capacitacao-cead.uapi.edu.br/ login/index.php. This VLE is available at the network server of the CEAD of the educational institution. Consequently, the DLO is used to support the classroom teaching of nursing diagnostic reasoning during the assessment of skin and skin appendages.

Figure 1 shows the navigation structure of the DLO and the order of the accessed information during its use. The learning object available on Moodle has 60 screens that present the DLO and the content of the four modules. Each module has an estimated duration of six hours, and the adaption of students to the Moodle environment has a duration of two hours. The total duration of the DLO is 26 hours.

Students can use the start menu to access the modules in any order. At the end of each module, the students are redirected to the start menu to continue to the next module they wish to access. This accessibility allows students to have a self-guided, independent learning experience. The presentation screen of the start menu also has action navigation buttons to move forward or backward between the individual screens in a continuous loop, which provides clarity and easily executable commands (Figure 2).

The content presented in module 1 helps students review the anatomy and physiology of the integumentary system and the skin healing process. It also includes reading suggestions of bibliographical support resources and exercises to review the studied content. Module 2 addresses the preparation and definition of a nursing diagnosis, and contains a description of the diagnosis according to the taxonomy of the North American Nursing Diagnosis Association International (NANDA-I). The end of the module contains reading suggestions of complementary resources and revision activities. 


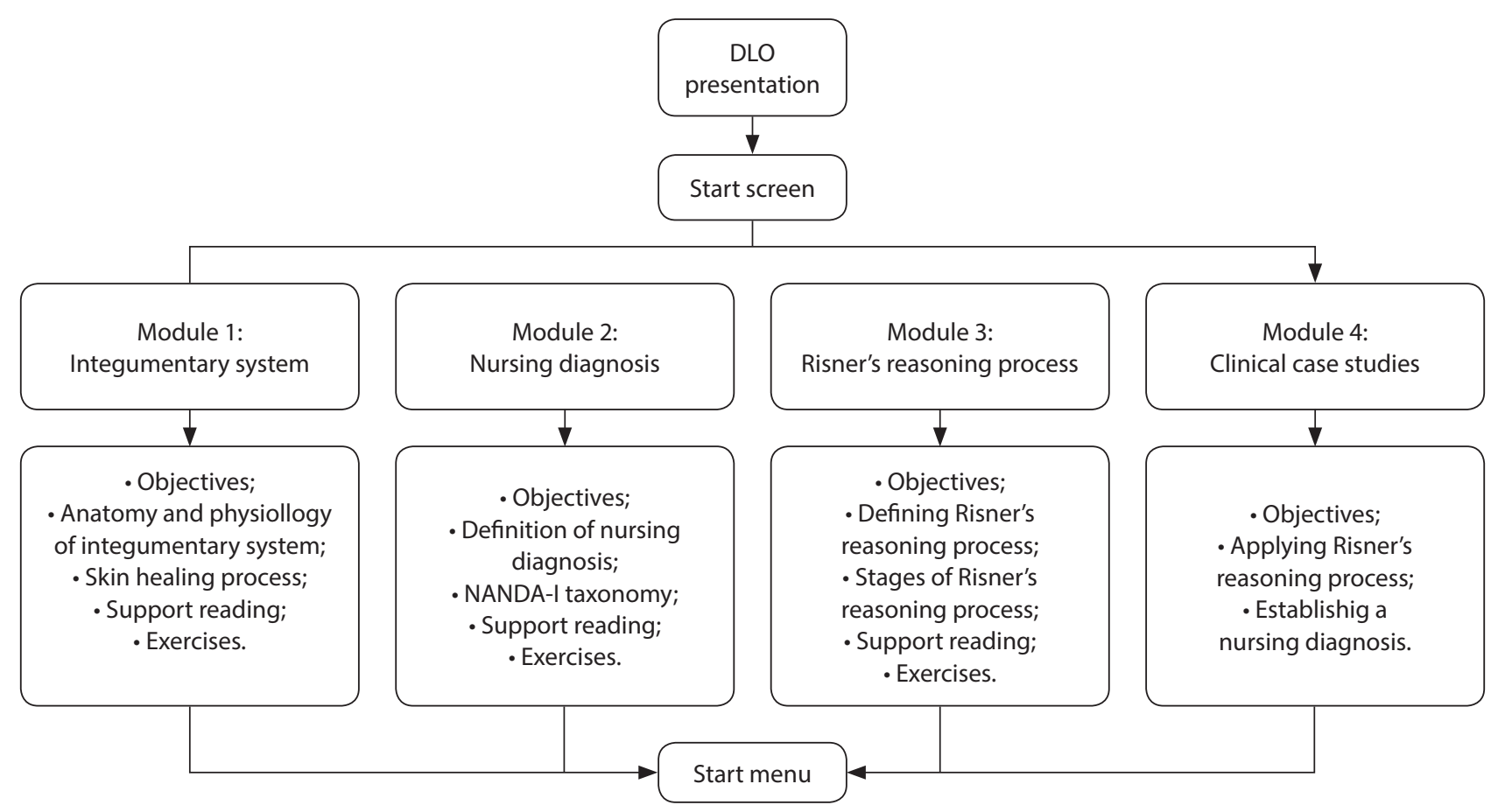

Figure 1 - Navigation structure of the DLO "Diagnostic Reasoning in Nursing Applied to the Integumentary System", Teresina, Piauí, 2014

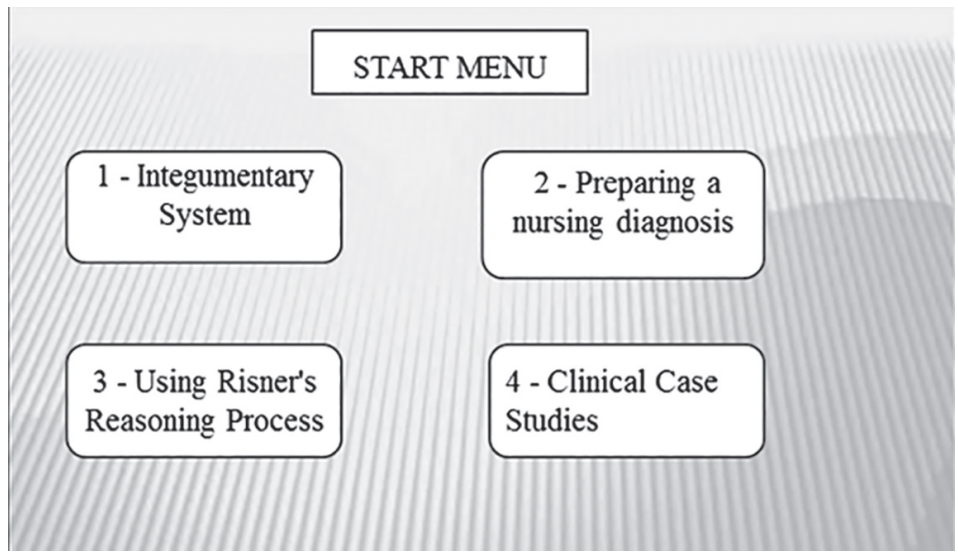

Figure 2 - Start screen of the DLO "Diagnostic Reasoning in Nursing Applied to the Integumentary System". Teresina, Piauí, 2014

The third module addresses the use of Risner's reasoning diagnostic process with the associated concepts and explanation of the recommended stages. It also contains reading suggestions of complementary resources and revision activities that promote the use of this reasoning process during clinical practice. The last module contains a presentation, questioning and discussion of the case studies that are used to apply Risner's reasoning diagnostic process in three clinical situations and associate theory with practice.

Each module contains a presentation screen that lists the learning objectives so students know what they are expected to learn by the end of the module (Figure 3).

With regard to the functional structure of the screens and the ergonomic homogeneity of the interface, the 
screens of the DLO are similar with the equal distribution of colours and buttons. The only exception is the section of the clinical case discussions, which includes a "view diagnosis" button that must be clicked at the end of the diagnostic reasoning process, and the "download NANDA diagnosis" button to download a PDF file with the nursing diagnosis as presented by NANDA-I (figures 4 and 5).

The three cases presented in the last module are based on real situations of the clinical practice in nursing care for a patient with a pressure ulcer and a patient with burns, and in primary care for a patient with psoriasis.

The revision activities at the end of each module were created using Hot Potatoes software. These activities consisted of fill-the-gap exercises, where the students provide the best and most assertive answer, and multiple choice exercises, where the students select the option that best defines the statement from a list of possible answers. When the students answer the question by choosing one of the available options, a pop-up message indicates whether the answer is correct or incorrect. If the answer is incorrect, the message "Incorrect, try again" appears on the screen.

\section{DISCUSSION}

During the development process of the DLO "Diagnostic Reasoning in Nursing Applied to the Integumentary System", we observed a growing number of published studies that addressed the use of ICTs in patient-oriented educational activities, in the nursing learning process and in the permanent education of healthcare professionals.

However, we only found one study that specifically addressed the creation of a learning object for diagnostic reasoning and nursing diagnoses related to preterm infants ${ }^{(11)}$, and we found no evidence of studies that used the ICTs to teach diagnostic reasoning during the evaluation of the integumentary system.

The use of ICTs in nursing education is necessary because these tools increase and extend the knowledge of nursing by creating challenges that enable the development of important skills for the emancipation of students in the knowledge society ${ }^{(12)}$.

The theoretical assumptions guided the creation of a digital learning resource that supports classroom teaching in undergraduate studies in nursing. The creation of this educational material was permeated by recent evidence that reveals that computers and ICTs are considered important instruments for effective learning ${ }^{(3,5,13-14)}$.

The development process of the DLO "Diagnostic Reasoning in Nursing Applied to the Integumentary System" for problem-based learning enabled an experience with individual repercussions by giving priority to systematic observation, analysis, the association of ideas, the extrapolation of the presented content, practical use and collective impact. The students were consequently involved in the collective construction of knowledge and the sharing of ideas and experiences, which culminated in a new way of thinking and doing.

The questioning process seeks to continuously reflect what is said, and develop from the dialogue and the grad-

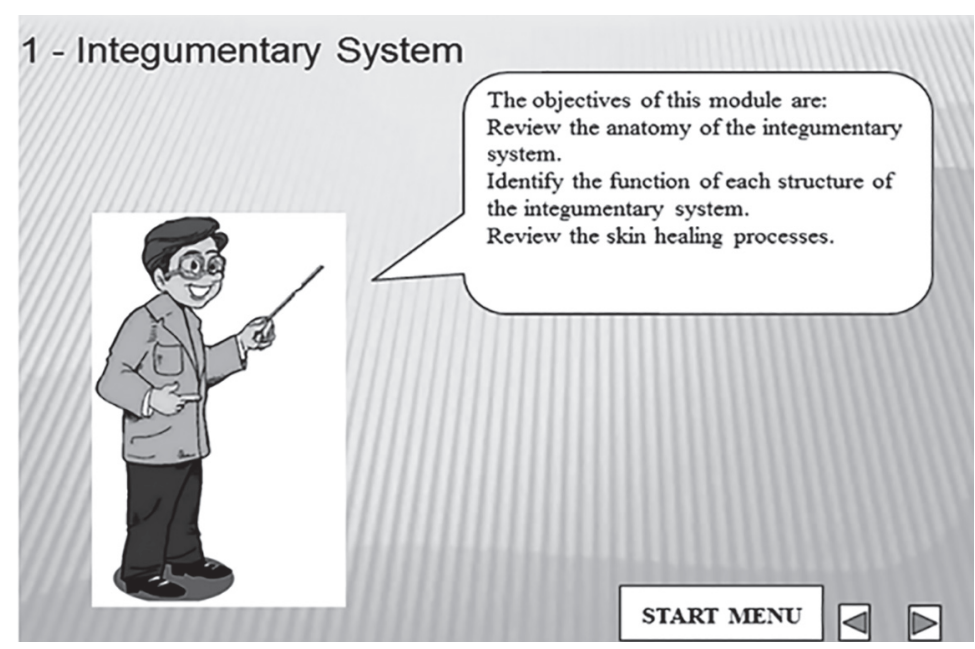

Figure 3 - Presentation screen of the objective of one of the DLO modules. Teresina, Piauí, 2014 


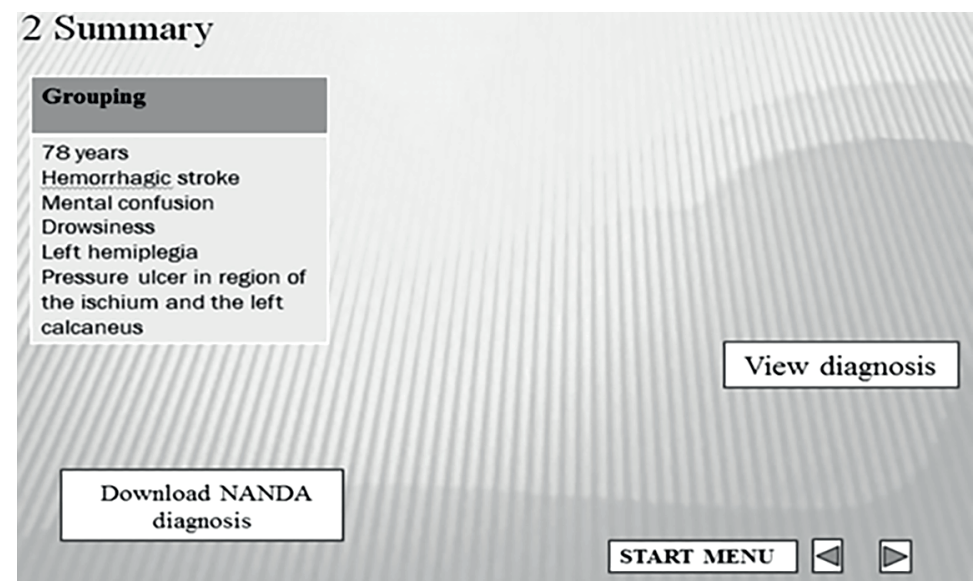

Figure 4 - Screen of the clinical case study presentation module of the DLO. Teresina, Piauí, 2014

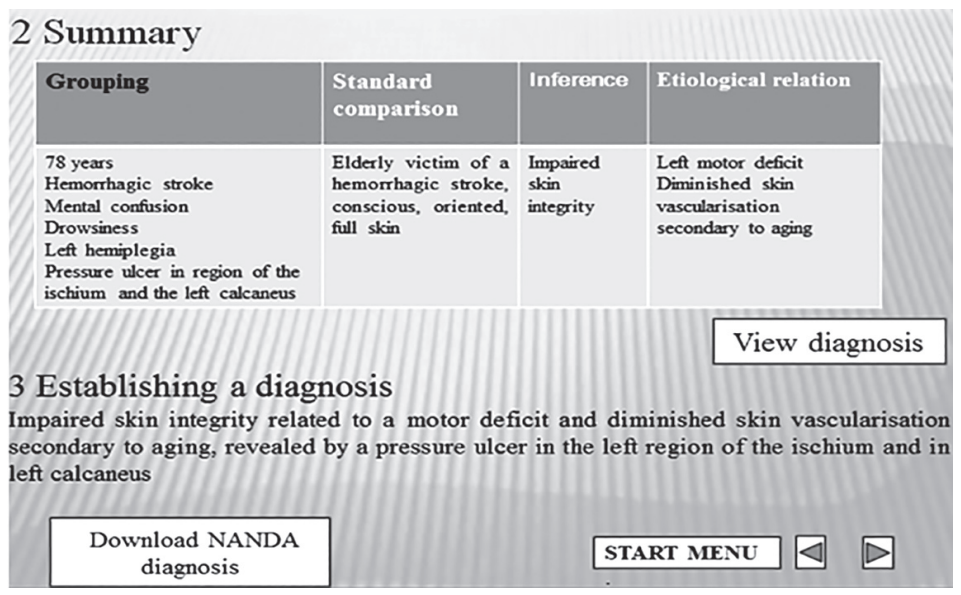

Figura 5 - Screen of the clinical case study presentation module of the DLO. Teresina, Piauí, 2014

ual critical unveiling of the situation to obtain a critical consciousness. The process of questioning the experienced daily reality helps students discover and understand facts or phenomena that were not previously perceived, thus transforming their way of thinking and acting ${ }^{(10)}$.

To further support problem-based learning, the DLO "Diagnostic Reasoning in Nursing Applied to the Integumentary System" was created to target clinical situations that contextually interconnect knowledge. In addition, it is expected to promote individual reflection of previously acquired knowledge and reflection when incorporating new knowledge, the stimulation of the power of decision, commitment and the critical stance by enumerating nursing diagnoses, autonomy and the participative management of students in the learning process.

Mediated by the pedagogical perspective of problem-based learning, the DLO that was planned and created according to diagnostic reasoning for the evaluation of the integumentary system features interactive educational content supported by the ICTs, which provide complementary tools to establish strategies that favour learning.

The three case studies presented in the DLO helped the students understand the presented health situation, the surveying, the theorizing and the systematization of 
the hypothesis to reach a nursing diagnosis that meets the needs of the patients in relation to the integumentary system.

In order to captivate the students, the content presented on the screen should be restricted to the moment that is being studied and follow a logical sequence, without excessive information. The language should also be simple, clear and objective to guarantee the accessibility of the content ${ }^{(15)}$.

To facilitate the design of the interface, a similar visual identity was adopted for all the screens of the learning object. The screens were also easy to navigate, with clear buttons and the grouping of information associated to each screen to ensure efficiency and prevent an overload of information.

\section{CONCLUSION}

The creation of the DLO "Diagnostic Reasoning in Nursing Applied to the Integumentary System" was based on the belief that this instrument supports the diagnostic reasoning process in the field of nursing for the evaluation of the integumentary system. It was also based on the belief that diagnostic reasoning in nursing is an essential practice that should serve as a basis for the exercise of this profession, considering that it is a cognitive process that surpasses the technical dimension of knowledge and is fundamental to formulate effective nursing diagnoses that reflect the needs of patients, especially during the evaluation of skin and skin appendages.

The further development of DLOs to improve diagnostic reasoning is important, since it would help create a nursing care model that targets valid and reliable methods and procedures and facilitate the collection of essential patient information in order to establish a safe clinical practice.

The methodological framework that was used according to the ADDIE model, based on the CID, was of great assistance and crucial to the success of the project because it allowed the development of a DLO and the achievement of the goals of this study. Bloom's revised taxonomy was also essential to establish the educational goals of each module of the DLO and of the problem-based learning pedagogy.

Studies that target the methodological aspects of creating a DLO are therefore considered important. These studies cover several dimensions of knowledge by demanding educational, technological and scientific efforts to carefully select the computer tools and theo- retical and methodological frameworks that will serve as a basis for the creation and management of educational resources.

We hope that this study will add value to the practices of nursing education by means of learning objects that teach diagnostic reasoning applied to the skin and skin appendages, and encourage further studies related to the use of DLOs in other fundamental knowledge areas of nursing. In addition, the DLO can support classroom teaching in nursing programmes and consequently support nursing education that focuses on the care practice of using diagnostic reasoning during skin assessments.

Although the content presented in the DLO was obtained from resources that were available in international and national literature on diagnostic reasoning and skin assessments, clinical evidence and the experiences of the authors of the study, it was not previously reviewed by nursing specialists, which constitutes a study limitation.

\section{REFERENCES}

1. Cruz, I. Moodle and nursing teaching: a brief experience report. Online Braz J Nurs. 2009;8(1).

2. Tamashiro LMC, Peres HHC. Desenvolvimento e avaliação de objetos de aprendizagem sobre administração de medicamentos por via intramuscular. Rev Latino-Am Enfermagem. 2014;22(5):716-23.

3. Corradi MI, Silva SH, Scalabrin EE. Virtual objects to support the teaching-learning process of physical examination in nursing. Acta Paul Enferm. 2011;24(3):348-53.

4. Schibeci R, Lake D, Phillips R, Lowe K, Cummings R, Miller E. Evaluating the use of learning objects in Australian and New Zealand schools. Comput Educ. 2008;50(1):271-83.

5. Frota NM, Barros LM, Araújo TM, Caldini LN, Nascimento JC, Caetano JA. Construção de uma tecnologia educacional para o ensino de enfermagem sobre punção venosa periférica. Rev Gaúcha Enferm. 2013;34(2):29-36.

6. Wong TKS, Chung JWY. Diagnostic reasoning processes using patient simulation in different learning environments. J Clin Nurs. 2002;11(1):65-72.

7. Risner PB. Diagnosis: analysis and synthesis of data. In: Griffith-Kenney JW, Christensen PJ. Nursing process application of theories, frameworks, and models. 2nd ed. St. Louis, Mosby; 1986.

8. Filatro A. Design instrucional contextualizado: educação e tecnologia. 3. ed. São Paulo: Editora SENAC; 2010.

9. Anderson LW, Krathwohl DR, Airasian PW, Cruikshank KA, Mayer RE, Pintrich PR, et al. A taxonomy for learning, teaching, and assessing. Complete ed. New York: Longman; 2001.

10. Freire, P. Educação como prática da liberdade. 19. ed. 32. Rio de Janeiro: Paz e Terra; 2009.

11. Goes FSN, Fonseca LMM, Furtado MCC, Leite AM, Scochi CGS. Evaluation of the virtual learning object"Diagnostic reasoning in nursing applied to preterm newborns". Rev. Latino-Am. Enfermagem. 2011;19(4):894-901. 
12. Silveira DT. As tecnologias da informação e comunicação e sua aplicação no campo de atuação da enfermagem [editorial]. Rev Gaúcha Enferm. 2007;28(4):453-4.

13. Tanaka RY, Catalan VM, Zemiack J, Pedro ENR, Cogo ALP, Silveira DT. Digital learning objects: an assessment of a tool for the practice of nursing education. Acta Paul Enferm. 2010;23(5):603-7.
14. Keser H, Özcan D. Current trends in educational technologies studies presented in World Conferences on Educational Sciences. Procedia Soc Behav Sci. 2011;15:3989-98.

15. Rangel EML, Mendes IAC, Cárnio EC, Alves LMM, Crispim JA, Mazzo A, et al. Evaluation by nursing students in virtual learning environments for teaching endocrine physiology. Acta Paul Enferm. 2011;24(3):327-33.

\section{Author's address:}

Cecília Passos Vaz da Costa

Av. Centenário, 3052, Aeroporto

64003-700 Teresina - Piauí.

E-mail: ceciliapassos14@yahoo.com.br
Received: 11.03.2015

Approved: 18.08.2015 